
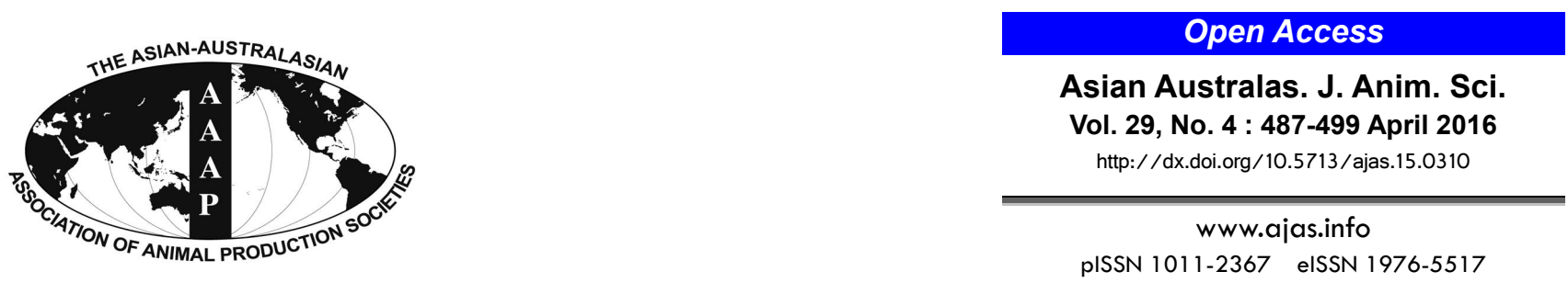

\title{
Effects of Steroid Hormone in Avian Follicles
}

\author{
R. E. Caicedo Rivas*, M. Paz-Calderón Nieto, and M. Kamiyoshi ${ }^{1}$ \\ Laboratory of Reproductive Endocrinology and malacology, School of Biology, \\ Autonomous University of Puebla, Puebla, CP 72570, México
}

\begin{abstract}
The aim of the present study was to examine the effects of testosterone $(\mathrm{T})$ and estradiol-17 $\beta$ ( $\left.\mathrm{E}_{2}\right)$ on the production of progesterone $\left(\mathrm{P}_{4}\right)$ by granulosa cells, and of the $\mathrm{E}_{2}$ on the production of $\mathrm{P}_{4}$ and $\mathrm{T}$ by theca internal cells. In the first experiment, granulosa cells isolated from the largest $\left(\mathrm{F}_{1}\right)$ and third largest $\left(\mathrm{F}_{3}\right)$ preovulatory follicle were incubated for $4 \mathrm{~h}$ in short-term culture system, $\mathrm{P}_{4}$ production by granulosa cells of both $\mathrm{F}_{1}$ and $\mathrm{F}_{3}$ was increased in a dose-dependent manner by ovine luteinizing hormone $(\mathrm{oLH})$, but not $\mathrm{T}$ or $\mathrm{E}_{2}$. In the second experiment, $\mathrm{F}_{1}$ and $\mathrm{F}_{3}$ granulosa cells cultured for $48 \mathrm{~h}$ in the developed monolayer culture system were recultured for an additional $48 \mathrm{~h}$ with increasing doses of various physiological active substances existing in the ovary, including $\mathrm{T}$ and $\mathrm{E}_{2}$. Basal $\mathrm{P}_{4}$ production for $48 \mathrm{~h}$ during 48 to $96 \mathrm{~h}$ of the cultured was about nine fold greater by $\mathrm{F}_{1}$ granulosa cells than by $\mathrm{F}_{3}$ granulosa cells. In substances examined oLH, chicken vasoactive intestinal polypeptide (cVIP) and T, but not $\mathrm{E}_{2}$, stimulated in a dosedependent manner $\mathrm{P}_{4}$ production in both $\mathrm{F}_{1}$ and $\mathrm{F}_{3}$ granulosa cells. In addition, when the time course of $\mathrm{P}_{4}$ production by $\mathrm{F}_{1}$ granulosa cells in response to oLH, cVIP, T and $\mathrm{E}_{2}$ was examined for $48 \mathrm{~h}$ during 48 to $96 \mathrm{~h}$ of culture, although $\mathrm{E}_{2}$ had no effect on $\mathrm{P}_{4}$ production by granulosa cells of $\mathrm{F}_{1}$ during the period from 48 to $96 \mathrm{~h}$ of culture, $\mathrm{P}_{4}$ production with oLH was found to be increased at $4 \mathrm{~h}$ of the culture, with a maximal 9.14 fold level at $6 \mathrm{~h}$. By contrast, $\mathrm{P}_{4}$ production with cVIP and T increased significantly $(\mathrm{p}<0.05)$ from 8 and 12 $\mathrm{h}$ of the culture, respectively, with maximal 6.50 fold response at $12 \mathrm{~h}$ and 6,48 fold responses at $36 \mathrm{~h}$. Furthermore, when $\mathrm{F}_{1}$ granulosa cells were precultured with $\mathrm{E}_{2}$ for various times before $4 \mathrm{~h}$ culture with oLH at $96 \mathrm{~h}$ of culture, the increase in $\mathrm{P}_{4}$ production in response to oLH with a dose-related manner was only found at a pretreatment time of more than $12 \mathrm{~h}$. In the third experiment, theca internal cells of $F_{1}, F_{2}$ and the largest third to fifth preovulatory follicles $\left(F_{3-5}\right)$ were incubated for $4 \mathrm{~h}$ in short-term culture system with increasing doses of $\mathrm{E}_{2}$. The production of $\mathrm{P}_{4}$ and $\mathrm{T}$ by theca internal cells were increased with the addition of $\mathrm{E}_{2}$ of $10^{-6} \mathrm{M}$. These increases were greater in smaller follicles. These results indicate that, in granulosa cells of the hen, T may have a direct stimulatory action in the long term on $\mathrm{P}_{4}$ production, and on $\mathrm{E}_{2}$ in long-term action which may enhance the sensitivity to $\mathrm{LH}$ for $\mathrm{P}_{4}$ production, and thus, in theca internal cells, $\mathrm{E}_{2}$ in short term action may stimulate the production of $\mathrm{P}_{4}$ and T. (Key Words: Preovulatory Follicles, Steroids Hormone, Granulosa, Theca Internal and External Cells)
\end{abstract}

\section{INTRODUCTION}

In most avian species only the left ovary becomes functional. Within this ovary there are several clearly recognizable groups of follicles, though each merges into the other in order of increasing size. The ovary in the

\footnotetext{
* Corresponding Author: R. E. Caicedo Rivas. Tel: +52-222-22955-00 (2739), Fax: +52-222-229-55-00 (7083), E-mail: ricaido @ yahoo.com

${ }^{1}$ Department of Animal Production and Utilization Sciences, the United Graduate School of Agricultural Sciences, Gifu University, Yanagido, Gifu 501-11, Japan.

Submitted Apr. 9, 2015; Revised May 11, 2015; Accepted Jun. 11, 2015
}

domestic fowl (Gallus domesticus) contains five or six largest preovulatory follicles arranged in a hierarchy. The ovum within each of the four largest follicles is surrounded by a single layer of granulosa cells. The granulosa layer is an avascular cell layer that produces primarily progestins and small amounts of androgens. The basement membrane is a multilayered laminar sheet that grows from approximately 0.2 to $1 \mathrm{~m}$ in thickness during stage 2 of follicular development. This membrane serves as a substratum for granulosa cells and separates the granulosa and theca layers (Rothwell and Salomon, 1977; Perry et al., 1978). The theca layer is composed of vascular, neural, connective and steroidogenic tissues and divided into theca 
internal and external layers. The theca internal layer is situated adjacent to the basement membrane and characterized by the presence of a discontinuous layer of fibroblast cells and theca cells, in small follicles, the theca cells may be grouped together into so-called theca glands. The theca external layer represents the major proportion of the follicles walls and is composed of sheets of fibroblastlike cells, numerous microfilaments, collagen fibers, and actin, but relatively few theca cells.

In the domestic fowl, progesterone $\left(\mathrm{P}_{4}\right)$ being produced in granulosa cells of the larger preovulatory follicles plays a key role in the endocrine control of the hypothalamichypophysial-ovarian axis. The production of $\mathrm{P}_{4}$ has been known to be stimulated mainly by luteinizing hormone (LH) (Schally et al., 1971; Hammond et al., 1980; Wells et al., 1981; Marrone and Hertelendy, 1983; Robinson and Renema, 1999; Hyang et al., 2007). However, physiological active substances existing in the ovary, including testosterone $(\mathrm{T})$ and estradiol-17 $\beta\left(\mathrm{E}_{2}\right)$, were recently shown to influence $\mathrm{P}_{4}$ production by granulosa cells of the hen (Johnson and Tilly, 1988; Johnson et al., 1988; Porter et al., 1989; Kamiyoshi et al., 1992; Von Engelhard and Groothuis, 2005). Porter et al. (1989), who examined $\mathrm{P}_{4}$ production in hen granulosa cells treated with androgens for 2 days, found that the treatment with androgens alone enhances the production of $\mathrm{P}_{4}$. Johnson et al. (1988) studied the influence of androgens and $\mathrm{E}_{2}$ on $\mathrm{P}_{4}$ production by hen granulosa cells in short-term culture, and they showed that androgens and $\mathrm{E}_{2}$ suppress basal and $\mathrm{LH}$-stimulated $\mathrm{P}_{4}$ production. Further, $\mathrm{P}_{4}$ production by hen granulosa cells in response to LH has been reported to be increased by the pretreatment with $\mathrm{E}_{2}$ for $48 \mathrm{~h}$ (Kamiyoshi et al., 1992; Groothuis et al., 2005). However, the influence of androgens and estrogens on the production of $\mathrm{P}_{4}$ in hen granulosa cells is not fully understood. Also, to the best of our knowledge, there are no reports that examined the effect of $E_{2}$ on the production of $\mathrm{P}_{4}$ and $\mathrm{T}$ by theca internal cells.

Johnson and Tilly (1988), who examined the effect of vasoactive intestinal polypeptide (VIP) on the production of $\mathrm{P}_{4}$ and cAMP in hen granulosa cells, found that the action of VIP on the $\mathrm{P}_{4}$ production had been delayed, because a significant increase in $\mathrm{P}_{4}$ production caused by VIP was not found until after $8 \mathrm{~h}$ of culture. However, in most reports studying a physiological effect of VIP on $\mathrm{P}_{4}$ production by hen granulosa cells in vitro, the effect has been examined by short-term culture system in floating condition of cells. Generally, it is virtually impossible to examine the longterm actions of hormones in a cell suspension culture.

Therefore, to evaluate the ability of $\mathrm{T}$ and $\mathrm{E}_{2}$ to affect $\mathrm{P}_{4}$ production in granulosa cells, and to study whether $\mathrm{E}_{2}$ affects the production of $\mathrm{P}_{4}$ and $\mathrm{T}$ in theca internal cells, the objectives of the present study were i) to determine whether or not the short-term cultures for $4 \mathrm{~h}$ with $\mathrm{T}$ and $\mathrm{E}_{2}$ affect the $\mathrm{P}_{4}$ production by granulosa cells isolated from the largest $\left(F_{1}\right)$ and third largest $\left(F_{3}\right)$ preovulatory follicle of the hen; ii) to determine, by using the developed monolayer culture system, whether or not the long term cultures for 48 $h$ with $T, E_{2}$ prostaglandin $E_{1}\left(P E_{1}\right)$, prostaglandin $F_{2} \alpha$ $\left(\mathrm{PGF}_{2} \alpha\right)$, epinephrine (E), norepinephrine (NE) mesotocin (MT), arginine vasotocin (AVT) and chicken vasoactive intestinal peptide (cVIP) which has been reported to exist in the follicles of the hen, or with ovine gonadotropins, affect the $\mathrm{P}_{4}$ production by $\mathrm{F}_{1}$ and $\mathrm{F}_{3}$ granulosa cells of the hen; iii) to examine the time course of the $\mathrm{P}_{4}$ production by $\mathrm{F}_{1}$ granulosa cells cultured with ovine luteinizing hormone $(\mathrm{oLH})$, cVIP and $\mathrm{T}$, which stimulated $\mathrm{P}_{4}$ production by $\mathrm{F}_{1}$ granulosa cells in substances examined, and furthermore whether or not the pretreatment with $\mathrm{E}_{2}$ affects the responsiveness of granulosa cells for $\mathrm{P}_{4}$ production and the effectiveness depends on the time of pretreatment; iv) to determine whether $E_{2}$ for short term affects the productions of $\mathrm{P}_{4}$ and $\mathrm{T}$ by theca internal cells of $\mathrm{F}_{1}$ and $\mathrm{F}_{3-5}$ of the hen.

\section{MATERIALS AND METHODS}

\section{Birds and collection of follicles}

Birds used were White Leghorn hens laying more than 4 eggs in a sequence of one-day pause between sequences. They had been kept in individual cages with feed and water provided ad libitum. In each experiment, 4 to 10 laying hens were killed 1 to $2 \mathrm{~h}$ after oviposition, and $\mathrm{F}_{1}$ and $\mathrm{F}_{3}$ in the experiments for granulosa cells or $F_{1}, F_{2}$ and $F_{3-5}$ in the experiments for theca internal cells were immediately excised, and granulosa layer and theca layer were separated from the excised follicle according to the method of Huang and Nalbandov (1979).

\section{Hormones and reagents}

The National Hormones and Pituitary Program kindly provided the oLH (NIH-oLH-S26, NIDDK) and (ovine follicle stimulating hormone (oFSH) (NIH-oFSH-S20, NIDDK). $\mathrm{P}_{4}, \mathrm{~T}, \mathrm{E}_{2}, \mathrm{E}, \mathrm{NE}, \mathrm{PGF}_{2} \alpha, \mathrm{PGE}_{1}$, corticosterone (B), bovine transferrin, porcine insulin and bovine serum albumin (BSA, fraction V) were purchased from sigma Chemical Co. (St. Louis, MO, USA). cVIP was obtained from Peninsula Laboratories, Inc. (Belmont, CA, USA). The AVT and MT were purchased from Biochemist Inc. (Bubendorf, Switzerland). Antisera to $\mathrm{P}_{4}$ and $\mathrm{T}$ were the generous gift of RIA Center of Gunma University. $(1,2,6$, $\left.7-{ }^{3} \mathrm{H}\right) \mathrm{P}_{4},\left(1,2,6,7-{ }^{3} \mathrm{H}\right) \mathrm{T}$ and ASC-II scintillators were obtained from Amersham International plc. (Buckinghamshire, UK). Mc Coy's 5a medium without serum and Ham's F12 medium were obtained from Gibco Life Technologies Inc. (Grand Island, NY, USA). Fetal calf 
serum was purchased from Boëhringer Mannheim (Mannheim, Germany).

\section{Dispersion and culture of granulosa cells for short-term culture}

After removing the outer fibrous tissues and the separation of the granulosa layer according to the method of Huang and Nalbandov (1979), pooled granulosa layers were placed in $10 \mathrm{~mL}$ Medium 199 supplemented with $10 \mathrm{mM}$ Hepes and $0.08 \%$ collagenase in a $50 \mathrm{~mL}$ plastic centrifuge tube, and then incubated for $5 \mathrm{~min}$ while shaking at 120 cycle/min in a bath kept at $37^{\circ} \mathrm{C}$. After the incubation, the dispersion was aspirated and expelled for approximately 30 $\mathrm{s}$ with a plastic syringe, and centrifuged at $250 \times \mathrm{g}$ for $5 \mathrm{~min}$ at $4^{\circ} \mathrm{C}$. The pellet was redispersed in $10 \mathrm{~mL}$ Medium 199 supplemented with $10 \mathrm{mM}$ Hepes, gently stirred for 1 to 2 min, filtered through a nylon gauze (mesh size, $60 \mathrm{~m}$ ) into a sterile plastic tube, and centrifuged at $250 \times \mathrm{g}$ for $5 \mathrm{~min}$ at $4^{\circ} \mathrm{C}$. The cell pellet was washed twice with $20 \mathrm{~mL}$ Medium 199 supplemented with $10 \mathrm{mM}$ Hepes and then once with $20 \mathrm{~mL}$ of the culture medium containing $10 \mathrm{mM}$ Hepes and $0.4 \%$ BSA in Medium 199. The final washed pellet was suspended in $10 \mathrm{~mL}$ of the culture medium, and the number of living and dead cells in the suspension was counted on a hemocytometer following trypan blue exclusion. The viability of the cells was more than $95 \%$. After the cell count, the cells at the density of $2 \times 10^{5}$ cells $/ \mathrm{mL} /$ tube were incubated for $4 \mathrm{~h}$ at $37^{\circ} \mathrm{C}$ with or without increasing doses (5 to $160 \mathrm{ng} / \mathrm{mL}$ ) of ovine LH (oLH; NIH-oLH-S26, NIDDK) or ovine FSH (oFSH; NIH-oFSH-S20, NIDDK). After culture, the granulosa cells were stored $-20^{\circ} \mathrm{C}$.

\section{Dispersion and culture of theca internal cells for short- term culture}

After removing the outer fibrous tissues and the separation of the granulosa layer, the remainder of each follicle (theca folliculi) was inverted, and incubated for 30 min in Medium 199 containing $10 \mathrm{mM}$ Hepes and $0.2 \%$ collagenase. Theca internal layer was gently scraped off with a scalpel blade until the color of tissue changed from pink to near white, and returned to Medium 199 containing $10 \mathrm{mM}$ Hepes and $0.2 \%$ collagenase, then further incubated for $25 \mathrm{~min}$. During the incubation with collagenase, mechanical dispersion was performed every 5 min with a syringe. The remaining theca external layer was minced into about $2 \mathrm{~mm}$ square pieces, and incubated for $60 \mathrm{~min}$ in Medium 199 containing $10 \mathrm{mM}$ Hepes and $0.2 \%$ collagenase with mechanical disruption of tissue every 15 min of interval with a syringe. The cell suspensions of theca internal and theca external were filtrated though a nylon gauze ( mesh size, $60 \mathrm{~m}$ ) and were centrifuged twice instead of once at $400 \times \mathrm{g}$ for $10 \mathrm{~min}$ at $4^{\circ} \mathrm{C}$. The cell pellet was resuspended in Medium 199 containing 40\% Percoll and centrifuged at $400 \times \mathrm{g}$ for $20 \mathrm{~min}$. Top layer containing theca cell was removed and pelleted by centrifugation at $400 \times \mathrm{g}$ for $10 \mathrm{~min}$.

The cell pellet was suspended in culture medium containing $10 \mathrm{mM}$ Hepes and 0.2\% BSA in Medium 199, and centrifuged at $400 \times \mathrm{g} 10 \mathrm{~min}$. After the cell count on a hemocytometer following a trypan blue dye exclusion, suspensions of living cells of the theca internal and theca external were diluted to the cell density of $2 \times 10^{5}$ cells $/ 0.5$ $\mathrm{mL}$ with culture medium. oLH (NIH-oLH-S26, NIDDK) and oFSH (NIH-oFSH-S20, NIDDK) were diluted in culture medium at the concentrations of $0.1,1,10$, and 100 $\mathrm{ng} / 0.5 \mathrm{~mL}$ and added to the cell suspensions. The cells with an incubation volume of $1 \mathrm{~mL}$ were incubated for $4 \mathrm{~h}$ at $37^{\circ} \mathrm{C}$. After incubation, the theca cells were stored at $-20^{\circ} \mathrm{C}$.

\section{Dispersion of granulosa cells for long-term culture}

Granulosa layers were separated from the excised follicles according to the method of Huang and Nalbandov (1979). After washing with Hepes buffer (25 mM Hepes; $137 \mathrm{mM} \mathrm{NaCl} ; 5 \mathrm{mM} \mathrm{KCl} ; 0.7 \mathrm{mM} \mathrm{Na} \mathrm{HPO}_{4} 2 \mathrm{H}_{2} \mathrm{O} ; 10$ $\mathrm{mM}$ glucose; $360 \mathrm{mM} \mathrm{CaCl}{ }_{2} 2 \mathrm{H}_{2} \mathrm{O} ; \mathrm{pH}$ 7.4) supplemented with $100 \mathrm{U} / \mathrm{mL}$ penicillin and $100 \mu \mathrm{g} / \mathrm{mL}$ streptomycin sulfate, the pooled granulosa layers were placed in $10 \mathrm{~mL}$ Hepes buffer containing $0.08 \%$ collagenase in a $50 \mathrm{~mL}$ plastic centrifuge tube, and then incubated for $5 \mathrm{~min}$ while shaking at $120 \mathrm{cycle} / \mathrm{min}$ in a bath kept at $37^{\circ} \mathrm{C}$. After the incubation, the dispersion was aspirated and expelled for approximately $30 \mathrm{~s}$ with a plastic syringe, and centrifuged at $250 \times \mathrm{g}$ for $5 \mathrm{~min}$ at $4^{\circ} \mathrm{C}$. The pellet was redispersed in 10 $\mathrm{mL}$ Hepes buffer, gently stirred for 1 to $2 \mathrm{~min}$, filtrated though nylon gauze (mesh size, $60 \mu \mathrm{m}$ ) into a sterile plastic tube, and centrifuged at $250 \times \mathrm{g}$ for $5 \mathrm{~min}$ at $4^{\circ} \mathrm{C}$. The cell pellet was washed twice with $20 \mathrm{~mL}$ Hepes buffer and once with $20 \mathrm{~mL}$ of desired medium. The final washed pellet was suspended in $10 \mathrm{~mL}$ of desired medium and the number of living and dead cells in the suspension was counted on a hemocytometer following the trypan blue exclusion. The viability of cells was always more than $95 \%$.

\section{Experiment 1: Effect of oLH, T, and $E_{2}$ for short term $P 4$ production of granulosa cells}

To examine the effect of oLH, T, and $\mathrm{E}_{2}$ for short term on $\mathrm{P}_{4}$ production of granulosa cells, $\mathrm{F}_{1}$ and $\mathrm{F}_{3}$ granulosa cells $\left(2 \times 10^{5}\right.$ cells $/ \mathrm{mL} /$ tube $)$ were incubated for $4 \mathrm{~h}$ with or without increasing concentrations of oLH $(10,20,40,80$, and $160 \mathrm{ng} / \mathrm{mL}), \mathrm{T}\left(10^{-9}, 10^{-8}, 10^{-7}\right.$, and $\left.10^{-6} \mathrm{M}\right)$ and $\mathrm{E}_{2}\left(10^{-}\right.$ $9,10^{-8}, 10^{-7}$, and $\left.10^{-6} \mathrm{M}\right)$. After the incubation, the cultured medium was collected and stored at $-20^{\circ} \mathrm{C}$.

Experiment 2: Monolayer cultured method of granulosa 
cells

To select an optimum fined medium for the long-term culture of hen granulosa cells, the cell density of $F_{1}$ granulosa cells was adjusted to $7.5 \times 10^{5}$ cells $/ \mathrm{mL}$ with the following media supplemented with $10 \mathrm{mM}$ Hepes, $2 \mathrm{mM}$ L-glutamine, $100 \mathrm{U} / \mathrm{mL}$ penicillin and $100 \mu \mathrm{g} / \mathrm{mL}$ streptomycin sulfate: Mc Coy's 5a medium, Ham's F12 medium, basic medium consisting of a 1:1 mixture of Mc Coy's 5a medium and Ham's F12 medium, serumcontaining medium supplemented with $10 \%$ (vol/ $/ \mathrm{vol})$ fetal calf serum to the basic medium or serum-free medium supplemented with insulin $(20 \mathrm{mU} / \mathrm{mL})$, transferrin (5 $\mu \mathrm{g} / \mathrm{mL}$ ), BSA ( $4 \mathrm{mg} / \mathrm{mL}$ ) and B ( $20 \mathrm{ng} / \mathrm{mL}$ ) to the basic medium. Aliquots $(0.4 \mathrm{~mL})$ of the cell suspension containing $3 \times 10^{5}$ living cells were placed in wells of the 24well plastic culture dishes (Nunc Int. Med., Sigma-Aldrich, Inc. St. Louis, Mo, USA) and cultured at $38^{\circ} \mathrm{C}$ under a water-saturated atmosphere of $95 \%$ air and $5 \% \mathrm{CO}_{2}$. Medium was changed every $48 \mathrm{~h}$. At 48 and $96 \mathrm{~h}$ of the culture, after morphological appearance of cell was observed, the medium was collected and stored at $-20^{\circ} \mathrm{C}$, and the cell number was counted on a hemocytometer after the treatment with $0.05 \%$ trypsin- $0.02 \%$ ethylenediaminetetra-acetic acid (EDTA)-Hepes buffer.

To examine the responsiveness to oLH of $\mathrm{P}_{4}$ production by hen granulosa cells cultured for $96 \mathrm{~h}$ in serum-containing medium and serum-free medium described above, $F_{1}$ granulosa cells $\left(3 \times 10^{5}\right.$ cells/well) were cultured for $96 \mathrm{~h}$ in serum-containing medium or serum-free medium. Medium was renewed every $48 \mathrm{~h}$. After removal of the medium at 96 $\mathrm{h}$ of the culture, fresh serum-free medium containing oLH $(100 \mathrm{ng} / \mathrm{mL})$ nothing else was added and then cultured for 4 h. After the culture, the medium was collected and stored at $-20^{\circ} \mathrm{C}$, and the number of cells were counted as described above.

Experiment 3: $P_{4}$ production by granulosa cells in longterm culture with physiological active substances

To evaluate the $\mathrm{P}_{4}$ production by hen granulosa cells cultured for a long-term, granulosa cells $\left(3 \times 10^{5}\right.$ cells $/$ well $)$ of the $F_{1}$ and $F_{3}$ cultured for $48 \mathrm{~h}$ in serum-free medium were cultured for an additional $48 \mathrm{~h}$ with serum-free medium containing one of the following materials: oLH and $\mathrm{oFSH}$ at the concentrations of $0.1,1,10$, and $100 \mathrm{ng} / \mathrm{mL}$, respectively, and cVIP, AVT, MT, T, $\mathrm{E}_{2}, \mathrm{E}, \mathrm{NE}, \mathrm{PGE}_{1}$, and $\mathrm{PGF}_{2 \alpha}$ at the concentrations of $10^{-9}, 10^{-8}, 10^{-7}$, and $10^{-6} \mathrm{M}$, respectively. After the culture, the medium was collected and stored at $-20^{\circ} \mathrm{C}$, and the cell number in cultures with $\mathrm{oLH}, \mathrm{cVIP}$, and $\mathrm{T}$, which were shown to enhance $\mathrm{P}_{4}$ production by granulosa cells in preliminary experiments, was counted as described above.
Experiment 4: Time course of $P_{4}$ production by granulosa cells with oLH, cVIP, T, and $\mathrm{E}_{2}$

In order to evaluate the time course of $\mathrm{P}_{4}$ production in culture with oLH, cVIP, $\mathrm{T}$, and $\mathrm{E}_{2}$, after $\mathrm{F}_{1}$ granulosa cells $\left(3 \times 10^{5}\right.$ cells/well $)$ were cultured for $48 \mathrm{~h}$ in serum-free medium, the cells were washed and cultured in serum-free medium with or without oLH $(100 \mathrm{ng} / \mathrm{mL}), \mathrm{cVIP}\left(10^{-6} \mathrm{M}\right)$, $\mathrm{T}\left(10^{-6} \mathrm{M}\right)$ and $\mathrm{E}_{2}\left(10^{-6} \mathrm{M}\right)$ for $4,6,8,12,24,36$, or $48 \mathrm{~h}$, respectively. After the culture, the medium was frozen and stored at $-20^{\circ} \mathrm{C}$.

\section{Experiment 5: Effect of $E_{2}$ pretreatment on LH- stimulated $\mathrm{P}_{4}$ production by granulosa cells}

To know whether or not the pretreatment with $E_{2}$ affects the responsiveness of granulosa cells to $\mathrm{LH}$ for $\mathrm{P}_{4}$ production, after the preculture for $48 \mathrm{~h}$ with or without increasing doses $\left(10^{-9}, 10^{-8}, 10^{-7}\right.$, and $\left.10^{-6} \mathrm{M}\right)$ of $\mathrm{E}_{2}$, the $\mathrm{F}_{1}$ granulosa cells $\left(3 \times 10^{5}\right.$ cells/well $)$ were washed and recultured again with or without oLH $(100 \mathrm{ng} / \mathrm{mL})$ for $4 \mathrm{~h}$. After the culture, the medium was stored at $-20^{\circ} \mathrm{C}$.

To examine whether or not the enhancement of LHstimulated $\mathrm{P}_{4}$ production with $\mathrm{E}_{2}$ is dependent on the time of pretreatment, $F_{1}$ granulosa cells $\left(3 \times 10^{5}\right.$ cells/well $)$ cultured for $48 \mathrm{~h}$ were pretreated with $\mathrm{E}_{2}\left(10^{-6} \mathrm{M}\right)$ in different period of the time for $6,12,24,36$, or $48 \mathrm{~h}$, respectively, before $96 \mathrm{~h}$ of culture. After this pretreatment, the cells were washed and then recultured again with or without $\mathrm{oLH}(100 \mathrm{ng} / \mathrm{mL})$ for $4 \mathrm{~h}$. After the $4 \mathrm{~h}$ cultures, the medium was stored at $-20^{\circ} \mathrm{C}$.

\section{Experiment 6: Effect of $E_{2}$ in short-term culture on $P_{4}$ and $T$ production by theca internal cells}

To examine whether $\mathrm{E}_{2}$ affects $\mathrm{P}_{4}$ and $\mathrm{T}$ production by theca internal cells of $F_{1}, F_{2}$, and $F_{3-5}$, theca internal cells $\left(2 \times 10^{5}\right.$ cells $/ \mathrm{mL} /$ tube $)$ were incubated for $4 \mathrm{~h}$ with or without $E_{2}$ at the concentrations of $10^{-9}, 10^{-8}, 10^{-7}$, and $10^{-6}$ $\mathrm{M}$ and oLH $(100 \mathrm{ng} / \mathrm{mL})$ and oFSH $(100 \mathrm{ng} / \mathrm{mL})$, respectively. After the incubation, the culture medium was collected and stored at $-20^{\circ} \mathrm{C}$.

\section{Progesterone and testosterone radioimmunoassay}

In this assay, The cross-reaction for the antisera was as follows: $\mathrm{P}_{4}$ antiserum $<0.1 \%$ with $17 \alpha$-hydroxy- $\mathrm{P}_{4},<0.06 \%$ with $\mathrm{T}, 0.006 \%$ with $\mathrm{E}_{2},<0.02 \%$ with dehydroepiandrosterone and negligible with other steroids: $\mathrm{T}$ antiserum $<0.0032 \%$ with $20 \alpha$-dihydro- $\mathrm{P}_{6}, \quad 0.0032 \%$ with $17 \alpha$-hydroxy- $\mathrm{P}_{4}$, $0.0097 \%$ with $\mathrm{P}_{4}, 0.0032 \%$ with pregnenolone, $0.0094 \%$ with cortisol, $0.0107 \%$ with deoxycorticosterone, $1.25 \%$ with androstenedione, $0.0057 \%$ with dehydroepiandrosterone, $0.004 \%$ with $E_{2}, 0.0032 \%$ estrone, $0.0032 \%$ with $17 \alpha$ hydroxypregnenolone, $0.0093 \%$ with $20 \beta$-hydroxy- $\mathrm{P}_{6}, \mathrm{E}_{2}$ antiserum $-3.2 \%$ with estrone, $1.77 \%$ with estriol, $0.8 \%$ with estradiol-17 $\alpha, 0.44 \%$ with androstenedione, $0.19 \%$ 
with $\mathrm{T}$ and negligible with other steroid. Radioactive $[1,2$, $\left.6,7-{ }^{3} \mathrm{H}\right] \mathrm{P}_{4},\left[1,2,6,7-{ }^{3} \mathrm{H}\right] \mathrm{T}$ were obtained from Amersham Corp. (UK). $\mathrm{P}_{4}$ in the medium was measured without extraction. In brief, $100 \mu \mathrm{L}$ of the sample dissolved in $1 \%$ BSA - 0.1 M phosphate saline buffer (PBS), $100 \mu \mathrm{L}$ of the steroid antiserum diluted with $1 \%$ normal rabbit serum- 0.05 M EDTA $-0.1 \mathrm{M}$ PBS and $100 \mu \mathrm{L}$ of $1 \% \mathrm{BSA}-0.1 \mathrm{M}$ PBS containing the ${ }^{3} \mathrm{H}$ steroid of about $25.000 \mathrm{cpm}$ were mixed in glass tubes, and incubated for $24 \mathrm{~h}$ at $4{ }^{\circ} \mathrm{C}$. For the separation of bound and unbound steroid, $0.2 \mathrm{~mL}$ of dextran-coated charcoal suspension consisting of $6.5 \mathrm{~g}$ charcoal Norit A and $0.65 \mathrm{~g}$ dextran T-70 (Pharmacia, Uppsala, Sweden) per liter of 0.01 M PBS was added, and the tubes were kept in an ice bath for exactly $30 \mathrm{~min}$. After centrifugation at $1,500 \times \mathrm{g}$ for $15 \mathrm{~min}$ at $4^{\circ} \mathrm{C}$, the supernatant was decanted into a vial containing $4 \mathrm{~mL}$ of ACS-II scintillator (Amersham Corp, UK) and vortexed for about $10 \mathrm{~s}$. On the following day, the radioactivity was counted for $5 \mathrm{~min}$. All samples were measured in duplicate. The assay sensitivity of $\mathrm{P}_{4}$ and $\mathrm{T}$ (more than a 2SD different from zero bound) were $2.5 \mathrm{pg}$ per tube in $\mathrm{P}_{4}$ and $\mathrm{T}$. Intra and interassay coefficients of variations of $\mathrm{P}_{4}$ and $\mathrm{T}$ were $6.0 \%$ and $12.5 \% ; 10.2 \%$ and $15.2 \%$, respectively.

\section{Statistical analyses}

At least three independent replicates in each experiment were performed. Data was analyzed by analysis of variance, and followed by Duncan's new multiple range tests among more than two means and by Student's $t$ test between two means.

\section{RESULTS}

Experiment 1: Effect of $\mathrm{LH}, \mathrm{T}$, and $\mathrm{E}_{2}$ in short-term culture on $P_{4}$ production by granulosa cells

As shown in Figure 1 and 2, basal production of $\mathrm{P}_{4}$ for 4 $\mathrm{h}$ in short-term culture system was about five folds greater

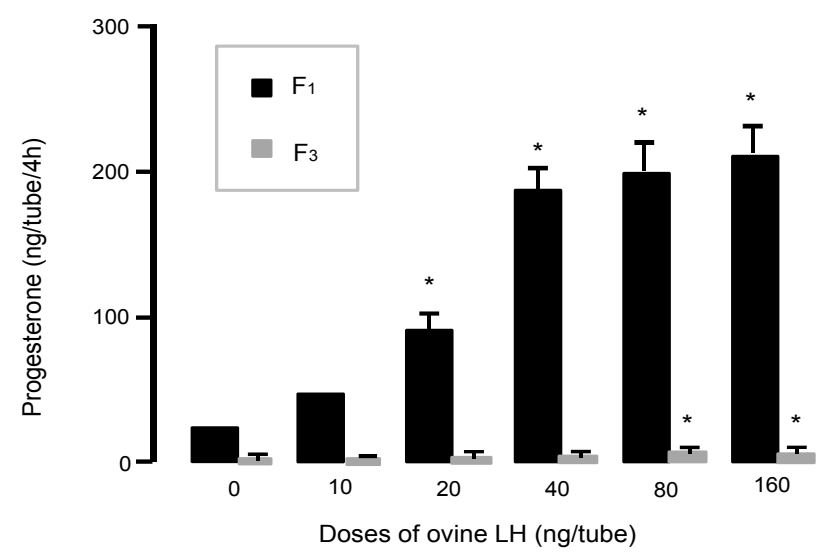

Figure 1. Progesterone production by granulosa cells of the largest and third largest preovulatory follicles cultured with ovine LH for $4 \mathrm{~h}$ in short-term culture system. LH, luteinizing hormone.

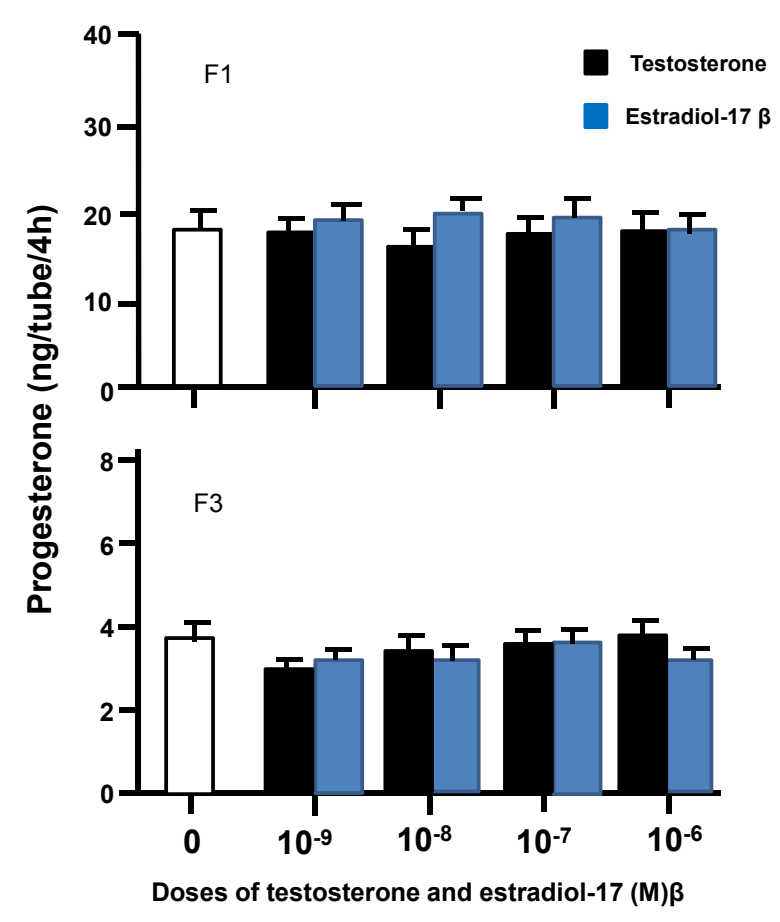

Figure 2. Progesterone production by granulose cells of the largest and third largest preovulatory follicles incubated with testosterone or estradiol- $17 \beta$ for $4 \mathrm{~h}$ in short-term culture system.

in $F_{1}$ granulosa cells than in $F_{3}$ granulosa cells. $P_{4}$ productions by the $F_{1}$ and $F_{3}$ granulosa cells were increased by addition of oLH from 20 and $80 \mathrm{ng} / \mathrm{mL}$, respectively, in a dose-related manner, but not by that of $T$ and $E_{2}$ in doses used.

\section{Experiment 2: Monolayer culture of granulosa cells}

When $\mathrm{F}_{1}$ granulosa cells of the hen were cultured for 96 $\mathrm{h}$ in Mc Coy's 5a medium without serum, Ham's F12 medium or basic medium consisting of a 1:1 mixture of Mc Coy's 5a and Ham's F12 medium, no surviving cells were observed after the cultures for $96 \mathrm{~h}$. However, when the cells were cultured in serum-containing medium, the basic medium supplemented with $10 \%$ fetal calf serum, or serumfree medium supplemented with insulin, transferrin, B and BSA, cells were alive and looked healthy under a microscope until the end of 96 h-culture (Figure 3). Granulosa cells $\left(3 \times 10^{5}\right.$ cells/well $)$ of the largest preovulatory follicles were cultured for $96 \mathrm{~h}$ in serum-free medium (Figure 3A-up side) supplemented with insulin 20 $\mathrm{mU} / \mathrm{mL}$, transferrin $5 \mu \mathrm{g} / \mathrm{mL}$, corticosterone $20 \mathrm{ng} / \mathrm{mL}$, and BSA $4 \mathrm{mg} / \mathrm{mL}$, the basal medium consisting of a $1: 1$ mixture of Mc Coy's 5a (without serum) and Hams-12F medium or serum-containing medium. (Figure 3B-down side) supplemented with $10 \% \mathrm{vol} / \mathrm{vol}$ of fetal calf serum to the basal medium. The medium was renewed every $48 \mathrm{~h}$. At 48 and $96 \mathrm{~h}$ of the culture, morphological appearance of cells was observed, cell number was counted and $\mathrm{P}_{4}$ in the 
A

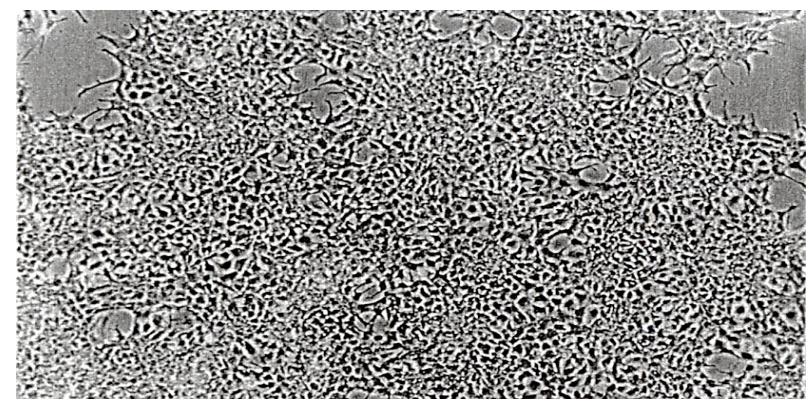

B

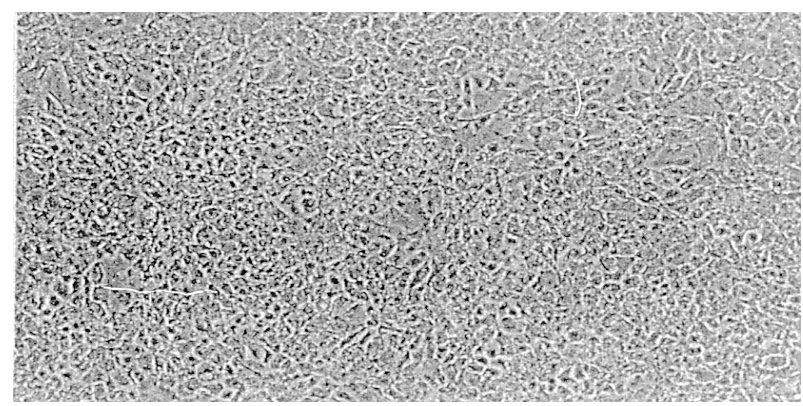

Figure 3. Morphological appearance $(\times 100)$ of hen granulosa cells cultured for $96 \mathrm{~h}$ in serum-free medium and serum-containing medium.

medium was measured. During the cultures the number of cells increased, although the latter was less in the serumfree medium than in the serum containing medium ( $<<0.05$; Figure 4). In contrast, basal $\mathrm{P}_{4}$ production was significantly greater in the cells cultured in serum-free medium than in those cultured in serum-containing medium $(\mathrm{p}<0.05$; Figure $5)$.

Furthermore, the responsiveness of the cells to oLH for $\mathrm{P}_{4}$ production, which was examined by measuring $\mathrm{P}_{4}$ in the medium after exposing to oLH $(100 \mathrm{ng} / \mathrm{mL})$ for $4 \mathrm{~h}$ following the $96 \mathrm{~h}$ of the culture, was significantly greater in the culture in serum-free medium than in that in serum- containing medium ( $<<0.05$; Figure 4). Based on the results described above, the serum-free medium supplemented with insulin, transferrin, B and BSA to the basic medium was used in the following experiments.

\section{Experiment 3: $\mathbf{P}_{4}$ production by granulosa cells in long- term culture}

As shown in Figure 6 and 7, basal $\mathrm{P}_{4}$ production for 48 $\mathrm{h}$ during 48 to $96 \mathrm{~h}$ of the culture was about nine folds greater in $F_{1}$ granulosa cells than $F_{3}$ granulosa cells. In both $\mathrm{F}_{1}$ and $\mathrm{F}_{3}$ granulosa cells, $\mathrm{P}_{4}$ production was increased in a dose dependent manner by oLH, cVIP, and $\mathrm{T}(\mathrm{p}<0.05)$ but not by other substances $(p>0.05)$, without affecting the number of cells. However, the rate of increase in $\mathrm{P}_{4}$ production compared with each basal $\mathrm{P}_{4}$ production was about half in $F_{3}$ granulosa cells than in $F_{1}$ granulosa cells. Also only in $\mathrm{F}_{3}$ granulosa cells, $\mathrm{P}_{4}$ production was stimulated 1.46 and 1.95 fold by oFSH at the concentrations of 10 and $100 \mathrm{ng} / \mathrm{mL}$, respectively.

Experiment 4: Time course of $\mathrm{P}_{4}$ production by granulosa cells with oLH, cVIP, $T$, and $E_{2}$

When the time course of $\mathrm{P}_{4}$ production by oLH, cVIP, T, and $E_{2}$ in $F_{1}$ granulosa cells was examined for $48 \mathrm{~h}$ during 48 to $96 \mathrm{~h}$ of culture (Figure 8), although $\mathrm{E}_{2}$ had no effect on $\mathrm{P}_{4}$ production by granulosa cells of $\mathrm{F}_{1}$ during the period from 48 until $96 \mathrm{~h}$ of the culture, the increase in $\mathrm{P}_{4}$ production by oLH was found at $4 \mathrm{~h}$ of the culture with the maximal 9.14-fold level at $6 \mathrm{~h}$. By contrast, the increases in $\mathrm{P}_{4}$ production by cVIP and T were found between 8 to $12 \mathrm{~h}$ of the culture $(\mathrm{p}<0.05)$ with the maximal 6.50 -fold level at $12 \mathrm{~h}$ and the 6.48 -fold level at $36 \mathrm{~h}$, respectively.

\section{Experiment 5: Effect of pretreatment with $E_{2}$ on LH-} stimulated $\mathrm{P}_{4}$ production by granulosa cells

As shown in Figure 9, $\mathrm{P}_{4}$ production in response to oLH for $4 \mathrm{~h}$ at or with $96 \mathrm{~h}$ of culture was increased with the
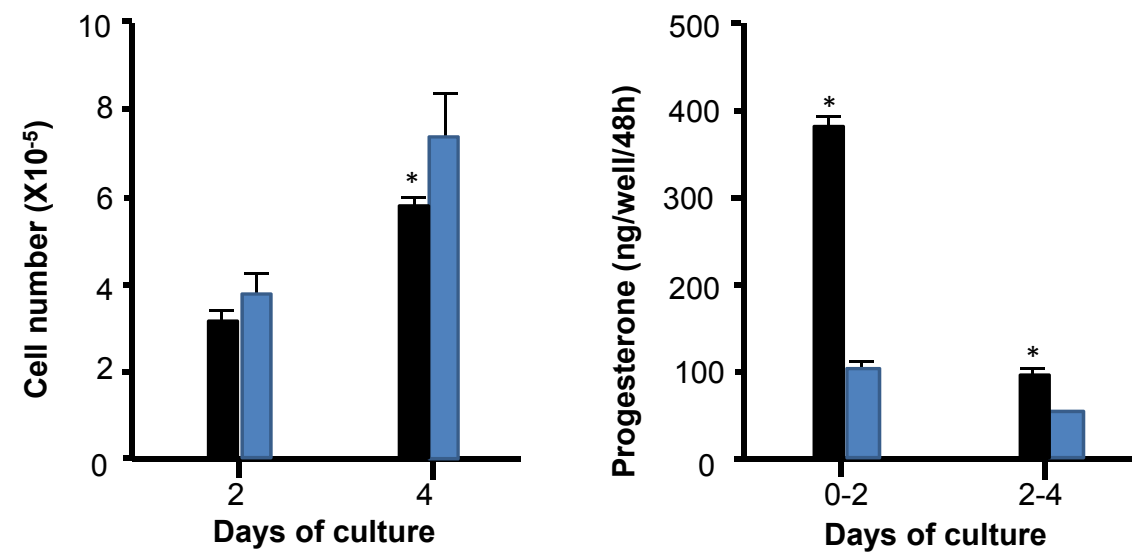

Figure 4. Cell proliferation and progesterone production of granulosa cells cultured in serum-free medium and serum-containing medium and their progesterone production. 

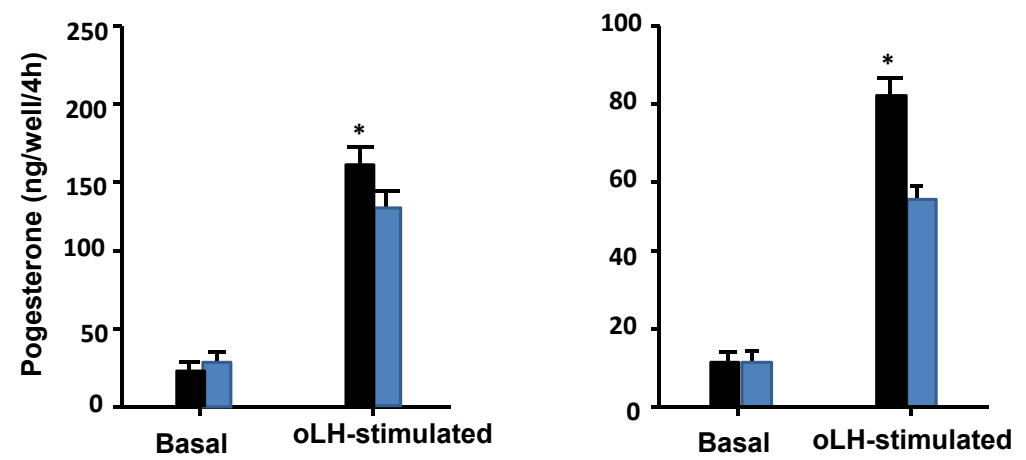

Figure 5. Basal and LH-stimulated progesterone production by granulosa cells cultured in serum-free medium and serum-containing medium. LH, luteinizing hormone.

pretreatment of $E_{2}$ for $48 \mathrm{~h}$ without affecting the cell number. This increase was greater as the dose of $E_{2}$ was increased. In addition, the enhancement of the responsiveness to oLH with $\mathrm{E}_{2}$ was found at more than $12 \mathrm{~h}$ of pretreatment $(\mathrm{p}<0.05$, Figure 10).

Experiment 6: Effect of $E_{2}$ and gonadotropins for shortterm on $\mathrm{P}_{4}$ production by theca internal cells

As shown in Figure 11 and $12, \mathrm{E}_{2}$ at the concentration of $10^{-6} \mathrm{M}$ was found to enhance the productions of $\mathrm{P}_{4}$ and $\mathrm{T}$ by theca internal cells. In addition, these increases were greater in smaller follicles in both steroid hormones. Also, oLH and oFSH stimulated the productions of $\mathrm{P}_{4}$ and $\mathrm{T}$ by theca internal cells with greater response in smaller follicles.

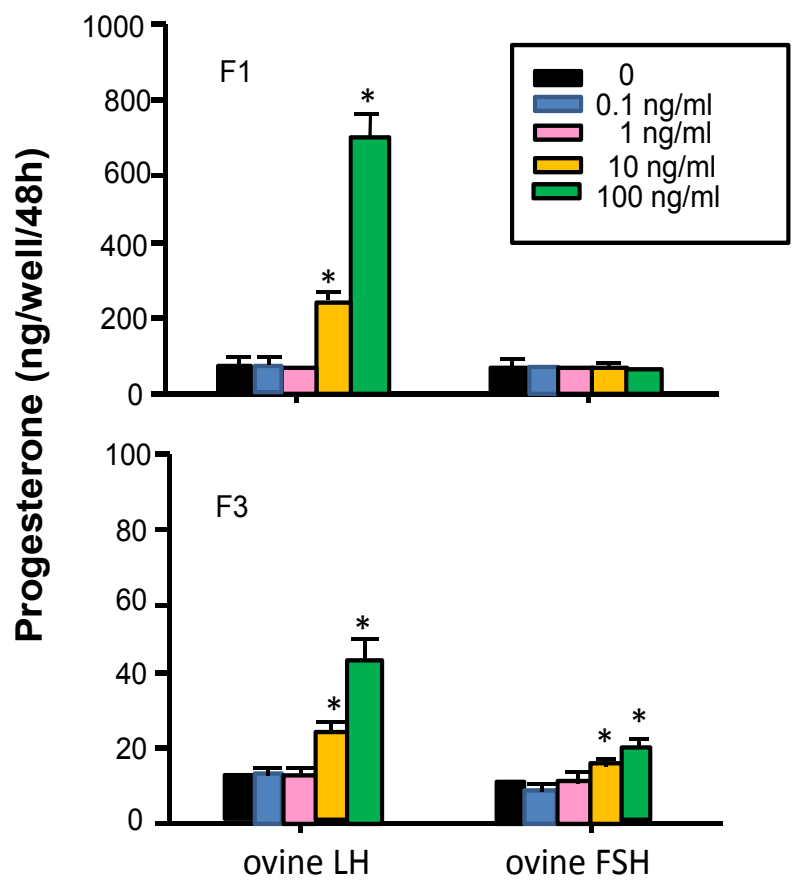

Figure 6. Progesterone production by granulosa cells of the largest and third largest preovulatory follicles cultured with ovine $\mathrm{LH}$ or FSH for $48 \mathrm{~h}$ in monolayer culture system. LH, luteinizing hormone; FSH, follicle stimulating hormone.

\section{DISCUSSION}

In the present experiments, a 1:1 mixture of Mc Coy's 5a medium and Ham's F12 medium was used as a basic medium. Mc Coy's 5a medium contains large amounts of amino acids (Mikami, 1980), while Ham's F12 medium is composed of a number of components (Ham, 1965). Mc Coy's 5a medium, Ham's F12 medium, and the basic medium did not support the survival of the cultured hen granulosa cells during $96 \mathrm{~h}$ of the cultures. However, when the combination of insulin, transferrin, B and BSA or fetal calf serum, which is known to enhance growth and functions of the cells (Heuson et al., 1967; Griffith, 1970; Channing et al., 1976; Barnes and Hammond, 1980; Orly et al., 1980), were added to the basic medium, healthy cells were maintained for at least $96 \mathrm{~h}$ and the cultured cells attached to the bottom of the wells, proliferated and responded to $\mathrm{LH}$ for $\mathrm{P}_{4}$ production. Although the rate of cell proliferation was lower than in cells cultured in serumcontaining medium, the cells cultured in serum-free medium showed greater basal and LH-stimulated $\mathrm{P}_{4}$ production, than those cultured in serum-containing medium. Thus, the serum-free medium is much more suitable for the study of the regulation mechanism of $\mathrm{P}_{4}$ production by hen granulosa cells, than the serumcontaining medium. Similar results have been report in the culture of mammalian granulosa cells (Orly et al., 1980; Barano and Hammond, 1985; Chin and Abayasekara, 2004). The use of serum-free medium supplemented with insulin, transferrin, B and BSA to the basic medium, enable to study the long action of hormones on $\mathrm{P}_{4}$ production by hen granulosa cells. Therefore, in the present experiments, the developed monolayer culture system using the chemically defined serum-free medium was used as the long-term culture system in the subsequent experiments.

In mammals, granulosa cells have been shown to metabolize androgens into estrogens (Evans et al., 1981; Wang and Bahr, 1983), but in birds, aromatase enzymes, capable of catalyzing the conversion of androgens into 


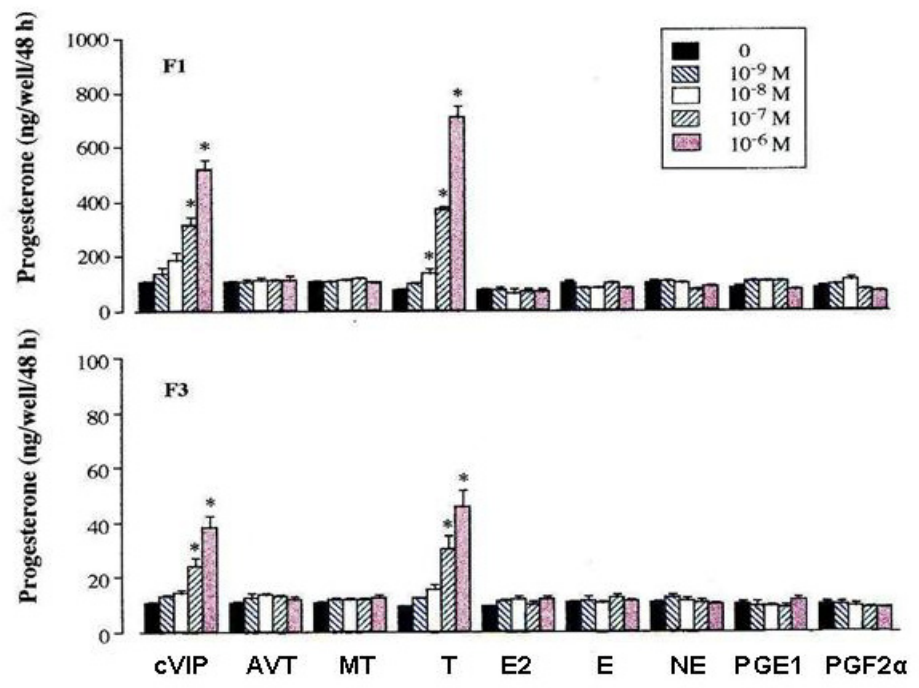

Figure 7. Progesterone production by granulosa cells of the largest and third largest preovulatory follicles cultured with various physiological substances for $48 \mathrm{~h}$ in monolayer system. cVIP, chicken vasoactive intestinal peptide; AVT, arginine vasotocin; MT, mesotocin testosterone; T, testosterone; E2, estradiol-17 $\beta$; E, epinephrine; NE, norepinephrine; $\mathrm{PGE}_{1}$, prostaglandin $\mathrm{E}_{1}$; PGF2 $\alpha$, prostaglandin $\mathrm{F}_{2} \alpha$.

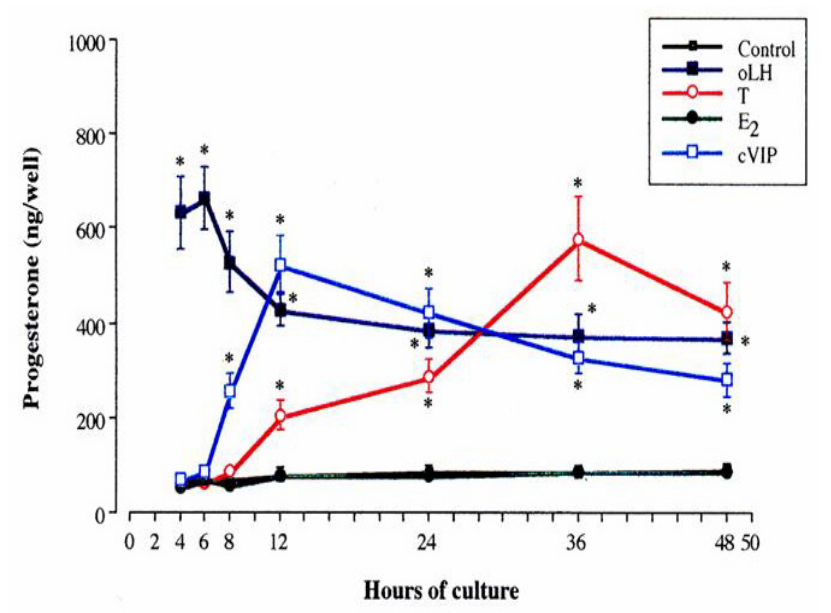

Figure 8. Time-course of progesterone production by granulosa cells of the largest preovulatory follicle with oLH, cVIP, testosterone and estradiol-17ß. oLH, ovine luteinizing hormone; cVIP, chicken vasoactive intestinal peptide.

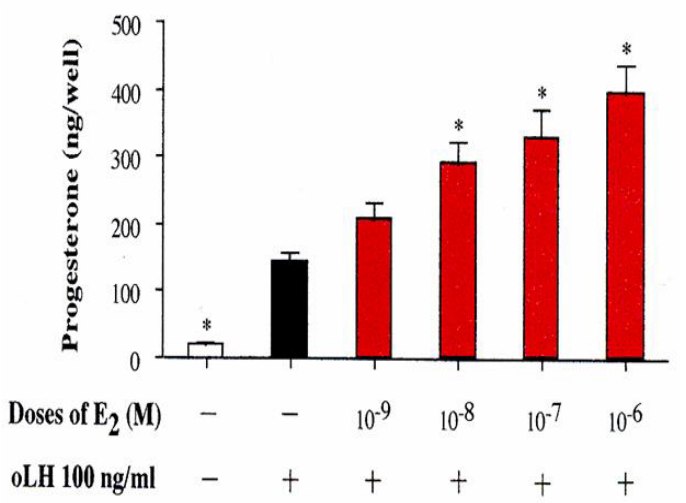

Figure 9. Effect of pretreatment with estradiol-17 $\beta$ on LHstimulated progesterone production. $\mathrm{LH}$, luteinizing hormone.

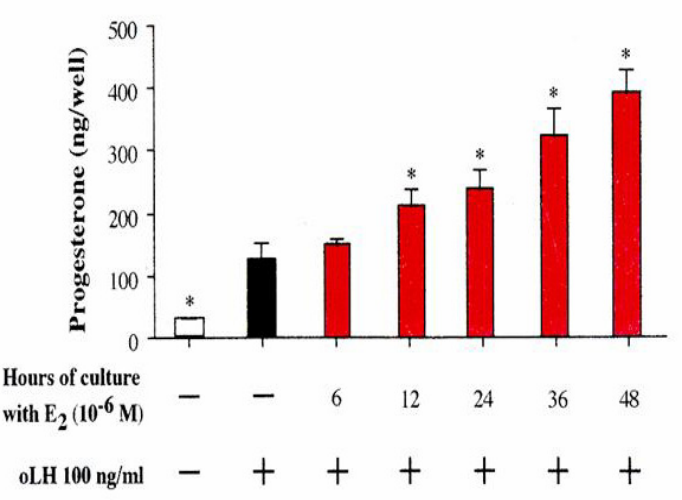

Figure 10. Time dependence for the enhancing effect of estradiol$17 \beta$ on LH-stimulated progesterone production. LH, luteinizing hormone. 


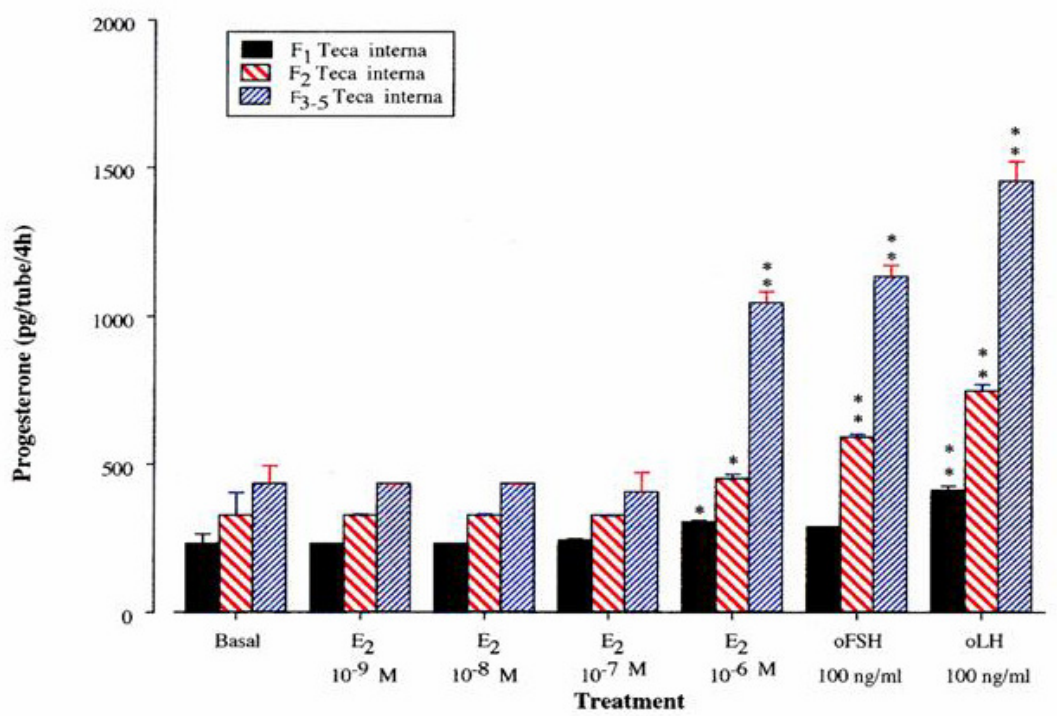

Figure 11. Progesterone production by theca interna cells of the largest, second and third-fifth preovulatory follicles incubated with estradiol-17 $\beta$ for $4 \mathrm{~h}$.

estrogens are not present in granulosa cells of preovulatory follicles (Armstrong, 1984). The present experiments showed that basal $\mathrm{P}_{4}$ production for $48 \mathrm{~h}$ during 48 to $96 \mathrm{~h}$ of culture is about nine-greater in $\mathrm{F}_{1}$ granulosa cells, than in $\mathrm{F}_{3}$ granulosa cells. Furthermore, LH, cVIP, and T, but not $\mathrm{E}_{2}$, stimulated $\mathrm{P}_{4}$ production without affecting the cell number in both $F_{1}$ and $F_{3}$ granulosa cells of hen granulosa cells with the treatment of these hormones for $48 \mathrm{~h}$. However, the rate of increase in $\mathrm{P}_{4}$ production by these hormones compared to the basal $\mathrm{P}_{4}$ production of each follicle was about half in $\mathrm{F}_{3}$ granulosa cells, than $\mathrm{F}_{1}$ granulosa cells. In addition, $\mathrm{FSH}$ was found to stimulated $\mathrm{P}_{4}$ production by $\mathrm{F}_{3}$ granulosa cells, but not by $F_{1}$ granulosa cells. These results are in agreement with those of many investigators in short-term culture system, showing that the production of $\mathrm{P}_{4}$ by hen granulosa cells in culture is dependent on follicular maturation (Asem and Hertelendy, 1986; Johnson, 1990; Johnson and Bridghan, 2001; Woods et al., 2007).

Johnson and Tilly (1988), who examined the effect of VIP on $\mathrm{P}_{4}$ production in $\mathrm{F}_{1}$ granulosa cells, have shown that a significant increase in $\mathrm{P}_{4}$ production in response to VIP is not detectable until after $8 \mathrm{~h}$ of the culture. Johnson et al. (1994), who found that immune-reactive VIP is located within the theca internal and theca external layers of nonhierarchical follicles in the hen, but not within granulosa cells of these follicles, reported that granulosa cells from 9

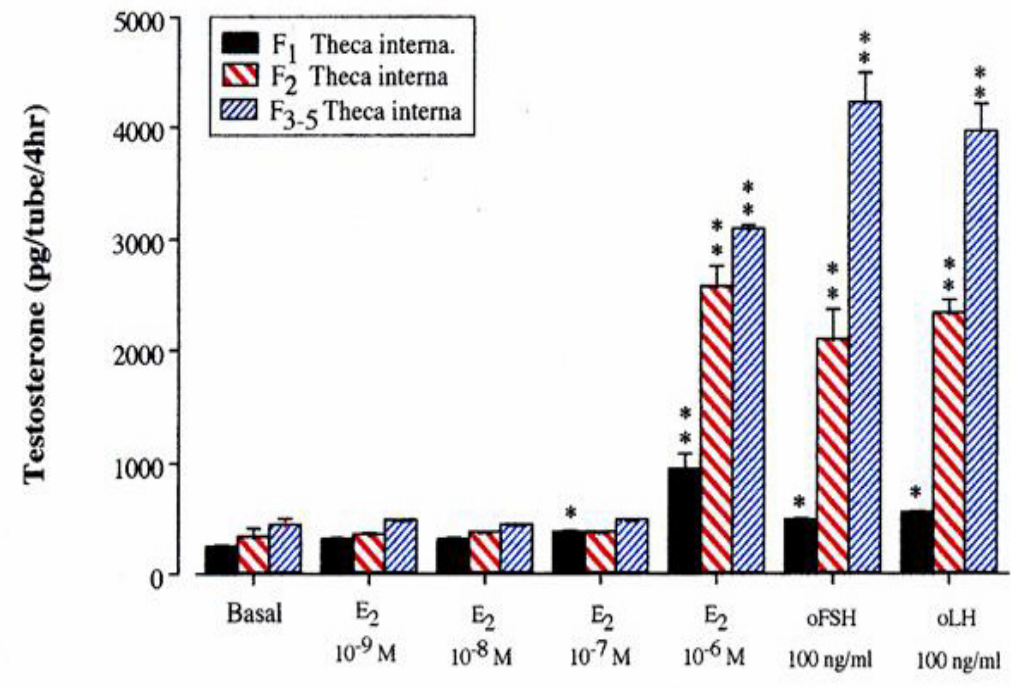

Treatment

Figure 12. Testosterone production by theca interna cells of the largest, second and third-fifth preovulatory follicles incubated with estradiol-17 $\beta$ for $4 \mathrm{~h}$. 

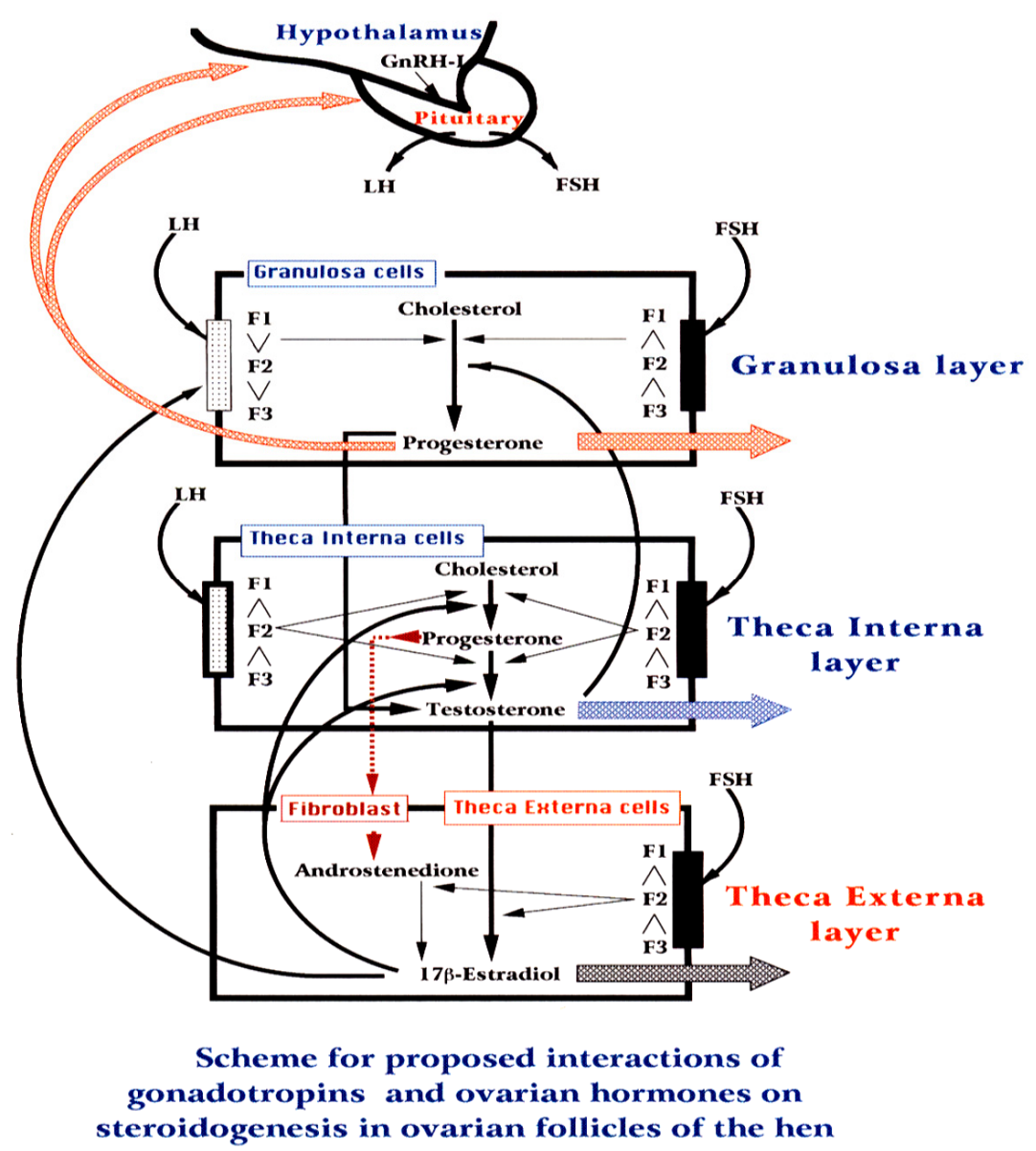

Figure 13. Scheme proposed by the interaction of gonadotropins and steroids hormones in ovarian follicles of domestic fowl.

to $12 \mathrm{~mm}$ small follicles responded to cVIP with increased $\mathrm{P}_{4}$ production in $3 \mathrm{~h}$-short incubation, whereas the $\mathrm{P}_{4}$ production in $\mathrm{F}_{1}$ granulosa cells was not increased with the treatment of cVIP for $3 \mathrm{~h}$. Although the present experiment, did not examine the time course of $\mathrm{P}_{4}$ production in response to cVIP in $\mathrm{F}_{3}$ granulosa cells, because basal $\mathrm{P}_{4}$ production by $F_{3}$ granulosa cells were less than by $F_{1}$ granulosa cells, $\mathrm{P}_{4}$ production in $\mathrm{F}_{1}$ granulosa cells treated with cVIP began to increase from $8 \mathrm{~h}$ of the treatment with the maximal increase at $12 \mathrm{~h}$. This is consistent with previous findings (Johnson and Tilly, 1988), that the action of VIP for stimulation of $\mathrm{P}_{4}$ production in $\mathrm{F}_{1}$ granulosa cells is required for long-term treatment. Recently, VIP receptors were found that exist in granulosa cells of the hen (Kikushi and Ishii, 1992). Therefore, the present results, together with previous results, indicate that VIP diffused from the theca layer of follicles have a direct stimulatory effect in a long-term action on $\mathrm{P}_{4}$ production by granulosa cells of the hen via receptors of VIP.

The present results, showed that the $\mathrm{P}_{4}$ production by hen granulosa cells is enhanced with the treatment of $\mathrm{T}$ alone for $48 \mathrm{~h}$, as reported by (Porter et al., 1989), who examined the production of $\mathrm{P}_{4}$ in hen granulosa cells treated with androgens for 2 days in 199 medium, supplemented with $5 \%$ porcine serum. However, in their report (Porter et al., 1989), the cultured cells were not attached to the bottom of the wells, and, moreover, the effect of androgens on $\mathrm{P}_{4}$ production were not examined except that with the treatment for 2 days, during the present experiments, the culture cells attached to the bottom of the wells showed the responsiveness to LH. Furthermore, the enhanced effect of $\mathrm{T}$ on the production of $\mathrm{P}_{4}$ was found to be necessary for treatment lasting more than $12 \mathrm{~h}$, with a maximal enhancement at $36 \mathrm{~h}$ of treatment. These results indicate that the long-term action of $\mathrm{T}$ clearly stimulate the production of $\mathrm{P}_{4}$ by hen granulosa cells, although hen granulosa cells maintained for several days in cultured have been report to metabolize $\mathrm{P}_{4}$ to a number of steroids, the principal of which is $3 \alpha$-hydroxy-5 $\beta$-pregnan-20one (Williams and Sharp 1978; Von Engelhard and Groothuis, 2005).

The present results showed that LH-stimulated $\mathrm{P}_{4}$ production in hen granulosa cells is enhanced by pretreatment with $\mathrm{E}_{2}$ for $48 \mathrm{~h}$ as in the previous report (Kamiyoshi et al., 1992). In addition, the enhancement of the LH-stimulated $\mathrm{P}_{4}$ production with $\mathrm{E}_{2}$ was found only 
when the granulosa cells were pretreated with $\mathrm{E}_{2}$ for more than $12 \mathrm{~h}$, indicating that $\mathrm{E}_{2}$ in long-term action may prime the hen granulosa cells to enhance the responsiveness to $\mathrm{LH}$ for $\mathrm{P}_{4}$ production.

In contrast, to the present results and of the Porter et al. (1989) and Johnson et al. (1988), who studied the influence of androgens and $\mathrm{E}_{2}$ on $\mathrm{P}_{4}$ production by hen granulosa cells in short-term culture, showed that androgens and $\mathrm{E}_{2}$ suppress basal and LH-stimulated $\mathrm{P}_{4}$ production. Subsequently, they suggested that androgens primarily act at the conversion site of cholesterol to pregnenolone $\left(\mathrm{P}_{5}\right)$ to suppress $\mathrm{P}_{4}$ production, while $\mathrm{E}_{2}$ for inhibition of $\mathrm{P}_{4}$ production acts at the conversion of $\mathrm{P}_{5}$ to $\mathrm{P}_{4}$ (Lee and Bahr, 1989; Caicedo et al., 2005). However, in their experiments on short-term culture of $F_{1}$ granulosa cells, inhibitory effects of androgens and $\mathrm{E}_{2}$ on $\mathrm{P}_{5}$ and $\mathrm{P}_{4}$ biosynthesis, respectively, are caused at high concentrations of $10^{-6}$ to $10^{-5} \mathrm{M}$ of these steroids. On the other hand, in the present experiments in long-term culture system, stimulatory effects of $\mathrm{T}$ and $\mathrm{E}_{2}$ on $\mathrm{P}_{4}$ production and responsiveness to $\mathrm{LH}$ were discovered from the concentration of $10^{-8} \mathrm{M}$, respectively, and further required for the treatment with those hormones for more than $12 \mathrm{~h}$. Therefore, disparities in the effect of $\mathrm{T}$ and $\mathrm{E}_{2}$ on $\mathrm{P}_{4}$ production, between the present and their experiments may be attributed to differences in concentrations of these hormones used and/or during of treatment.

In the present experiments, maximal, stimulatory effects of LH, VIP, and $\mathrm{T}$ on $\mathrm{P}_{4}$ production by hen granulosa cells were obtained at 6,12 , and $36 \mathrm{~h}$ of the respective treatments, and enhancement of the response to $\mathrm{LH}$ was greatest at $48 \mathrm{~h}$ of $E_{2}$ treatment, indicating that the action mechanism of these hormones may be different among these hormones. LH has been reported to promote $\mathrm{Ca}^{2+}$ mobilization and phosphoinositide hydrolysis, and to participate in $\mathrm{P}_{4}$ production by granulosa cells of the hen (Hertelendy et al., 1987; Krzysik-Walker et al., 2007). Although, the production of $\mathrm{P}_{4}$ by granulosa cells is known to be mediated via the adenylyl cyclase/cAMP second messenger system (Calvo and Bahr, 1983; Johnson and Tilly, 1988; Wu et al., 2003; Woods and Johnson, 2005), reported that VIP stimulates the production of cAMP, at a lower rate than $\mathrm{LH}$ because the effects of VIP on cAMP accumulation and $\mathrm{P}_{4}$ production in granulosa cells are not detectable, until after 8 $\mathrm{h}$ of the culture, while, LH significantly enhances cAMP accumulation and $\mathrm{P}_{4}$ production, after $4 \mathrm{~h}$ of the culture. As mentioned above, androgens and $\mathrm{E}_{2}$ in short-term culture is reported to suppress $\mathrm{P}_{4}$ production by hen granulosa cells (Johnson et al., 1988). According to the reports of Lee and Bahr (1989), androgens and $\mathrm{E}_{2}$ suppress $\mathrm{P}_{4}$ production in hen granulosa cells by inhibiting activities of cytochrome $\mathrm{P}$ 450 cholesterol site chain cleavage $\left(\mathrm{P}-450_{\mathrm{scc}}\right)$ and $3 \beta-$ hydroxysteroid dehydrogenase, respectively. Moreover, they suggested that the inhibitory effects of androgens and $E_{2}$ may not be mediated by these receptors, because $E_{2}$ has been found to act as a competitive inhibitor of $3 \beta$ hydroxysteroid dehydrogenase in isolated microsomes as well as in the presence of an estrogen receptor agonist (Freeman, 1985). In contrast to inhibitory effects of androgens and $\mathrm{E}_{2}$ on $\mathrm{P}_{4}$ production in short-term culture, the present experiments showed that $\mathrm{T}$ might has a facilitate action on $\mathrm{P}_{4}$ synthesis by granulosa cells in long-term culture. There are reports of androgen receptors in avian (Yoshimura et al., 1995) and mammalian granulosa cells (Hsueh et al., 1983). Nuclear estrogen receptor has been reported to be present in granulosa cells of the hen (Zarrow and Bastian, 1953; Kamiyoshi et al., 1986). Action of steroid hormones, via nuclear receptors is required for long duration to induce de novo synthesis of protein (Knecht et al., 1985). Also, estrogens have been known to induce the production of LH receptors in mammalian granulosa cells (Richards et al., 1976; Ritzhaup and Bahr, 1987). Therefore, the present finding, that over a long term $\mathrm{T}$ stimulate $\mathrm{P}_{4}$ production in hen granulosa cells and $E_{2}$ enhances the responsiveness to $\mathrm{LH}$ for $\mathrm{P}_{4}$ production by hen granulosa cells, would indicate that $\mathrm{T}$ and $\mathrm{E}_{2}$ may act via a receptormediated mechanism, and induce synthesis of enzymes participating in the production of $\mathrm{P}_{4}$ and synthesis of $\mathrm{LH}$ receptors, respectively.

In the present experiments it was found that $\mathrm{E}_{2}$ for short-terms, enhance the production of $\mathrm{P}_{4}$ and $\mathrm{T}$ by theca internal cells. These finding suggest that estrogens produced in theca external cells, may act in a paracrine manner, not only on granulosa cells, but also on theca internal cells. Furthermore, $\mathrm{E}_{2}$ advance the production of $\mathrm{P}_{4}$ and $\mathrm{T}$ in the theca internal cells, not only by gonadotropins, but estrogens as well. Although, the mechanism by which estrogens stimulate the production of $\mathrm{P}_{4}$ and $\mathrm{T}$ in the theca internal cells is unclear, estrogens may enhance the production of these hormones, by activating the enzymes participating in the synthesis of $\mathrm{P}_{4}$ and $\mathrm{T}$, because the stimulatory action of $\mathrm{E}_{2}$ for the production of $\mathrm{P}_{4}$ and $\mathrm{T}$ by theca internal cells occurred in a short term, compared with the stimulatory action of $\mathrm{T}$ and $\mathrm{E}_{2}$ for the production of $\mathrm{P}_{4}$ by granulosa cells (Li et al., 2001; Caicedo, 2004). However, further investigations are necessary to verify these concepts.

\section{IMPLICATIONS}

The results in vivo and in vitro, this study may suggest that $T$ and $E_{2}$ began to be produced in theca cells, granulosa acting on paracrine manner and is involved in the induction of LH surge before ovulation, and this is motivated by the increased sensitivity to $\mathrm{LH}$ in granulosa cells, respectively. 
Finally, based on this study and previous studies on the interaction of gonadotropin hormones and steroids on steroidogenesis in ovarian follicles of the domestic hen, in this study a new scheme of the mechanism of hormonal interplay of steroid hormones and gonadotropin hormones is proposed in the ovary of the domestic hen (Figure 13).

\section{CONFLICT OF INTEREST}

We certify that there is no conflict of interest with any financial organization regarding the material discussed in the manuscript.

\section{ACKNOWLEDGMENTS}

The authors would like to thanks Fukaya Masonori, Nonobe Yukiko and Yoshida Hitoshi for technical assistance and Kawashima Mitsuo for your advices; Drs. K. Wakabayashi, and M. Hattori, (Gunma University) kindly donated antisera to $\mathrm{P}_{4}$ and $\mathrm{T}$. This research was supported by Japanese Minister Education, Science and Culture, Japan.

\section{REFERENCES}

Armstrong, D. G. 1984. Ovarian aromatase activity in the domestic fowl (Gallus domesticus). J. Endocrinol. 100:81-86.

Asem, E. K. and F. Hertelendy. 1986. Steroidogenesis and cAMP production in isolated avian granulosa cells during follicular maturation: Lack of positive correlation. Acta Endocrimol. 113:289-297.

Barano, J. L. and J. M. Hammond. 1985. Serum-free medium enhances growth and differentiation of cultured pig granulosa cells. Endocrinology 116:51-58.

Barnes, J. L. S. and J. M. Hammond. 1980. Serum-free cell culture: A unifying approach. Cell 22:649-655.

Caicedo, R. E. 2004. Steroidogenesis in theca cells of chicken follicles. Tecnociencia 6:71-83.

Caicedo, R. E., J. L. Zumaquero, and J. D. Quintero. 2005. Effect of estrogen in the progesterone production in granulosa cells. Scientia 17:47-56.

Calvo, F. O. and J. M. Bahr. 1983. Adenylyl cyclase system of the small preovulatory follicles of the domestic hen: Responsiveness to follicle-stimulating hormone and luteinizing hormone. Biol. Reprod. 29:542-547.

Channing, C. P., V. Tsai, and D. Sachs. 1976. Role of insulin, cortisol in luteinization of porcine granulosa cells growth in chemically defined media. Biol. Reprod. 15:235-247.

Chin, E. C. and D. R. E. Abayasecara. 2004. Progesterone secretion by luteinizing human granulosa cells: A possible cAMP-dependent but PKA-independent mechanism involved in its regulation. J. Endocrinol. 183:51-60.

Erickson, G. F., C. Wang, and A. J. W. Hsuech. 1979. FSH induction of functional LH receptors in granulosa cells cultured in a chemically defined medium. Nature 279:336-338.

Evans, G., M. Dobias, G. J. King, and D. T. Armstrong. 1981. Estrogen, androgen, and progesterone biosynthesis by theca and granulosa of preovulatory follicles in the pig. Biol. Reprod. 25:673-682.

Freeman, D. A. 1985. Estradiol acts as a competitive inhibitor of the $3 \beta$-hidroxysteroid dehydrogenase $/ \Delta^{5}-\Delta^{4}$ isomerase enzyme of cultured Leydig tumor cells. Endocrinology 117:2127-2133.

Griffith, J. B. 1970. The effect of insulin on the growth and metabolism of the human diploid cell, WI-38. J. Cell Sci. 7:575-585.

Groothuis, T. G., W. Müller, N. von Engelhardt, C. Carere, and C. Eising. 2005. Maternal hormones as a tool to adjust offspring phenotype in avian species. Neurosci. Biobehav. Rev. 29:329352.

Ham, R. G. 1965. Clonal growth of mammalian cells in a chemically defined, synthetic medium. Proc. Natl. Acad. Sci. 53:288-293.

Hammond, R. W., D. W. Olson, R. B. Frenkel, H. V. Biellier, and F. Hertelendy. 1980. Prostaglandins and steroid hormones in plasma and ovarian follicles during the ovulation cycle of the domestic hen (Gallus domesticus). Gen. Comp. Endocrinol. 42:195-202.

Hertelendy, F., B. Nemecz, and E. K. Asem, 1987. Influence of follicular maturation on LH-promoted $\mathrm{Ca}^{2+}$ mobilization phosphoinositide hydrolysis in granulosa cells of the domestic fowl. Biol. Reprod. Suppl. 1:125.

Heuson, J. C., A. Coune, and R. Heimann. 1967. Cell proliferation induced by insulin in organ culture of rat mammary carcinoma. Exp. Cell Res. 45:351-360.

Hsueh, A. J. W., P. B. C. Jones, E. Y. Adashi, C. Wang, L. Z. Zhuang, and T. H. J. Welsh. 1983. Intraovarian mechanisms in the hormonal control of granulosa cell differentiation in rats. J. Reprod. Fertil. 69:325-342.

Huang, E. S. R. and A. V. Nalbandov. 1979. Steroidogenesis of chicken granulosa theca cells: in vitro incubation system. Biol. Reprod. 20:442-453.

Johnson, A. L. 1990. Steroidogenesis and actions of steroids in the hen ovary. Cri. Rev. Poult. Biol. 2:319-346.

Johnson, A. L. and J. T. Bridghan. 2001. Regulation of steroidogenic acute regulatory protein and luteinizing hormone receptor messenger ribonucleic acid in hen granulosa cells. Endocrinology 142:3116-3124.

Johnson, A. L., Z. Li, J. A. Gibney, and S. Malamed. 1994. Vasoactive intestinal peptide-induced expression of cytochrome P-450 cholesterol side-chain cleavage 17 $\alpha$ hydroxylase enzyme activity in hen granulosa cells. Biol. Reprod. 51:327-333.

Johnson, A. L. and J. L. Tilly. 1988. Effects of vasoactive intestinal peptide on steroid secretion and plasminogen activator activity in granulosa cells of the hen. Biol. Reprod. 38:296-303.

Johnson, P. A., C. Green, H. T. Lee, and J. M. Bahr. 1988. Inhibition of progesterone secretion from granulosa cells by estradiol and androgens in the domestic hen. Endocrinology 123:473-477.

Kamiyoshi, M., M. Kawashima, and K. Tanaka. 1992. Estrogens promote cultured granulosa cells of the hen for progesterone production in response to LH. Jpn. Poult. Sci, 29:91-97.

Kamiyoshi, M., T. Niwa, and K. Tanaka. 1986. Nuclear estrogen receptor bindings in granulosa cells estradiol-17 $\beta$ in follicular membranes of the ovary of the hen during the ovulatory cycle. 
Gen. Comp. Endocrinol. 61:428-435.

Kikushi, M. and S. Ishii. 1992. Changes in luteinizing hormone receptors in the granulosa and theca layers of the ovarian follicle during follicular maturation in the Japanese quail. Gen. Comp. Endocrinol. 85:124-137.

Knecht, M., C. H. T. Morris, and K. J. Catt. 1985. Estrogen dependence of luteinizing hormone receptor expression in cultured rat granulosa cells. Inhibition of granulosa cell development by the antiestrogens tamoxifen and keoxifene. Endocrinology 116:1771-1777.

Krzysik-Walker, S. M., Olga M. Ocón-Grove, S. B. Maddineni, G. L. Hendricks III, and R. Ramachandran. 2007. Identification of calcitonin expression in the chicken ovary: Influence of follicular maturation and ovarian steroids. Biol. Reprod. 4:626635.

Lee, H. T. and J. M. Bahr. 1989. Inhibitory sites of androgens and estradiol in progesterone biosynthesis in granulosa cells of the domestic hen. Endocrinology 125:760-765.

Li, X., H. Peegel, and K. M. J. Menon. 2001. Regulation of high density lipoprotein receptor messenger ribonucleic acid expression and cholesterol transport in theca-interstitial cells by insulin and human chorionic gonadotropin. Endocrinology 142:174-181.

Marrone, B. L. and F. Hertelendy. 1983. Steroidogenesis by avian ovarian cells: Effects of luteinizing hormone and substrate availability. Am. J. Physiol. 244:E487-E493.

Mikami, S. 1980. Hypothalamic control of the avian adenohypophysis. In: Biological Rhythmus in Birds: Neural Endocrine Aspects (Eds. Y. Tanabe, K Tanaka, and T. Ookawa). Jp. Sc. Soc. Press, Springer-Verlag, Heidelberg, Berlin, Germany. 17-32.

Orly, J., G. Sato, and G. F. Erickson. 1980. Serum suppresses the expression of hormonally induced functions in cultured granulosa cells. Cell 20:817-827.

Perry, M. M., A. B. Gilbert, and A. J. Evans. 1978. Electron microscope observations on the ovarian follicle of the domestic fowl during the rapid growth phase. J. Anat. 125:481497.

Porter, T. E., B. M. Hargis, J. L. Silsby, and M. E. El Halawani. 1989. Differential steroid production between theca interna and theca externa cells: A three-cell model for follicular steroidogenesis in avian species. Endocrinology 125:109-116.

Richards, J. S., J. J. Ireland, M. C. Rao, G. A. Bernath, A. R. J. Midgley, and L. E. J. Reichert. 1976. Ovarian follicular development in the rat: Hormone receptor regulation by estradiol, follicle stimulating hormone and luteinizing hormone. Endocrinology 99:1562-1570.

Ritzhaup, L. K. and J. M. Bahr. 1987. A decrease in FSH receptors of granulosa cells during follicular maturation in the domestic hen. J. Endocrinol. 115:303-310.
Robinson, F. E. and R. A. Renema. 1999. Principios del manejo de los foto períodos en Reproductoras de engorde. Editorial Cobb-Vantress Incorporation, Arkansas, USA. Boletin Técnico 7:1-6.

Rothwell, B. and S. E. Salomon. 1977. The ultrastructure of the follicle wall of the domestic fowl during the phase of rapid growth. Br. Poult. Sci. 18:605-610.

Schally, A. V., R. M. Nair, T. W. Redding, and A. Arimura. 1971. Isolation of the luteinizing hormone and follicle-stimulating hormone-releasing hormone from porcine hypothalamus. J. Biol. Chem. 23:7230-7236.

Seol, H. S., K Sato, Y. Matsubara, W. J. Schneider, and Y. Akiba. 2007. Modulation of sterol regulatory element binding protein2 in response to rapid follicle development in chickens. Comp. Biochem. Physiol. Part B: Biochem. Mol. Biol. 147:698-703.

Von Engelhard, N. K. and T. G. G. Groothuis. 2005. Measuring steroid hormones in avian eggs. Ann. NY Acad. Sci. 1046: 181-192.

Wang, S. C. and J. M. Bahr. 1983. Estradiol secretion by theca cells of the domestic hen during the ovulatory cycle. Biol. Reprod. 28:618-624.

Wells, J. W., H. R. Dick, and A. B. Gilbert. 1981. The biosynthesis of progesterone by fowl granulosa cells in vitro from ${ }^{14} \mathrm{C}$ labelled substrates. J. Steroid Biochem. 14:651-656.

Williams, J. B. and P. J. Sharp. 1978. Control of the preovulatory surge of luteinizing hormone in the hen (Gallus domesticus): The role of progesterone and androgens. J. Endocrinol. 77:5765 .

Woods, D. C. and A. L. Johnson. 2005. Regulation of folliclestimulating hormone-receptor messenger RNA in hen granulosa cells relative to follicle selection. Biol. Reprod. 72:643-650.

Woods, D. C., M. J. Haugen, and A. L. Johnson. 2007. Actions of epidermal growth factor receptor/mitogen-activated protein kinase and protein kinase $\mathrm{C}$ signaling in granulose cells from Gallus gallus are dependent upon stage of differentiation. Biol. Reprod. 77:61-70.

Wu, Q., S. Sucheta, A. Azhar, and K. M. J. Menon. 2003. Lipoprotein enhancement of ovarian theca-interstitial cell steroidogenesis: Relative contribution of scavenger receptor class B (type I) and adenosine 5- triphosphate-binding cassette (type A1) transporter in high-density lipoprotein-cholesterol transport and androgen synthesis. Endocrinology 144:24372445.

Yoshimura, Y., T. Okamoto, and T. Tamura. 1995. Effects of luteinizing hormone follicle-stimulating hormone on the progesterone receptor induction in chicken granulosa cells in vivo. Poult. Sci. 74:147-151.

Zarrow, M. X. and J. W. Bastian. 1953. Blockade of ovulation in the hen with adrenolytic and parasympatholytic drugs. Proc. Soc. Exp. Biol. Med. 84:457-459. 